\title{
Review \\ The Partial Contribution of Constructed Wetland Components (Roots, Gravel, Microorganisms) in the Removal of Phenols: A Mini Review
}

\author{
Eyal Kurzbaum 1,2,3 \\ 1 Shamir Research Institute, University of Haifa, Qatzrin 12900, Israel; ekurzbaum@univ.haifa.ac.il; \\ Tel.: +972-46123901; Fax: +972-46123930 \\ 2 Department of Geography and Environmental Studies, University of Haifa, Mount Carmel, \\ Haifa 3498838, Israel \\ 3 Department of Environmental Sciences, Tel-Hai College, Upper Galilee 1208088, Israel
}

check for

updates

Citation: Kurzbaum, E. The Partial Contribution of Constructed Wetland Components (Roots, Gravel,

Microorganisms) in the Removal of Phenols: A Mini Review. Water 2022, 14, 626. https://doi.org/10.3390/ w14040626

Academic Editors: Christos S Akratos and Ewa Wojciechowska

Received: 11 January 2022

Accepted: 15 February 2022

Published: 18 February 2022

Publisher's Note: MDPI stays neutral with regard to jurisdictional claims in published maps and institutional affiliations.

Copyright: (C) 2022 by the author. Licensee MDPI, Basel, Switzerland. This article is an open access article distributed under the terms and conditions of the Creative Commons Attribution (CC BY) license (https:// creativecommons.org/licenses/by/ $4.0 /)$

\begin{abstract}
Constructed wetlands (CW) have attracted growing interest in wastewater treatment research in the last 20 years, and have been investigated intensively worldwide. Many of the basic processes occurring in CWs have been qualitatively established; however, much quantitative knowledge is still lacking. In this mini review, the proportionate contributions of the different system components to removal of contaminants are examined. The main objective of this mini review is to provide a more in-depth assessment of the interactions between the porous bed, plants, and microorganisms during the removal of organic contaminants from the water in a subsurface flow CW system. In addition, a unique technique to study the partial contribution to the total removal of contaminants in a CW is described. Future studies in this field will expand our knowledge of any synergistic or antagonistic interactions between the components and facilitate improved CW construction and operation. Here, phenol will be used as a model industrial organic contaminant to illustrate our current understanding of the contributions of the different components to total removal. I will also discuss the various factors influencing the efficacy of bacteria, whether planktonic or as biofilm (on porous bed or plant roots), in subsurface flow CWs.
\end{abstract}

Keywords: constructed wetland; phenol; biodegradation; biofilm; PAH

\section{Introduction}

An efficient approach to treating anthropogenic discharge (e.g., wastewater, effluents from agriculture and industry, stormwater runoff) is to create a constructed wetland $(\mathrm{CW})$, which simulates natural marshland or swampland. These artificial wetlands employ physical, chemical, and/or biological methods, either consecutively or concurrently, to convert and extract different contaminants from the wastewater, and as such are highly intricate systems [1,2]. The CW concept offers comprehensive removal of organics, nutrients, and solids with relatively low construction costs, and lower operating and maintenance costs than those associated with mechanical treatment technologies, especially for small- to intermediate-sized communities where suitable land is available. In addition, CW systems provide additional benefits, such as pleasing esthetics and wildlife habitats. However, purification efficiencies may vary depending on temperature, season, and geographical region.

A common $\mathrm{CW}$ is the subsurface flow $\mathrm{CW}$ - a depression lined with a porous bed (such as gravel) layer that underlies the effluent layer and supports a range of plants. The porous bed enables the separation of suspended solids from the effluent, in addition to the sedimentation stage which usually occurs at the entrance to the facility. Moreover, the extensive root surface of the plants allows the extraction of nutrients such as phosphate and nitrogen, as well as heavy metals and some of the less easily removed organic components $[1,3,4]$. 
Most of the organic carbon components in CWs are removed by microorganisms, which usually exist in either planktonic (i.e., suspended) or sessile (i.e., as biofilms) form. Biofilms develop on the roots of plants or on the porous bed, forming specialized microniches and diverse communities; their activity differs greatly from that of conspecific planktonic cells, which are swept along with the water flow [5-7]. These systems and their myriad components and effects on the environment have been described extensively by others $[2-4,8]$. The interactions between the bacteria and the main system components - porous bed, plants, and effluent water-have been studied for some contaminants [8-11]; however, knowledge about such interactions remains insufficient with respect to phenols. The main system components of a subsurface flow $\mathrm{CW}$ and an experimental method to monitor the partial contribution of each component are illustrated in Figure 1.
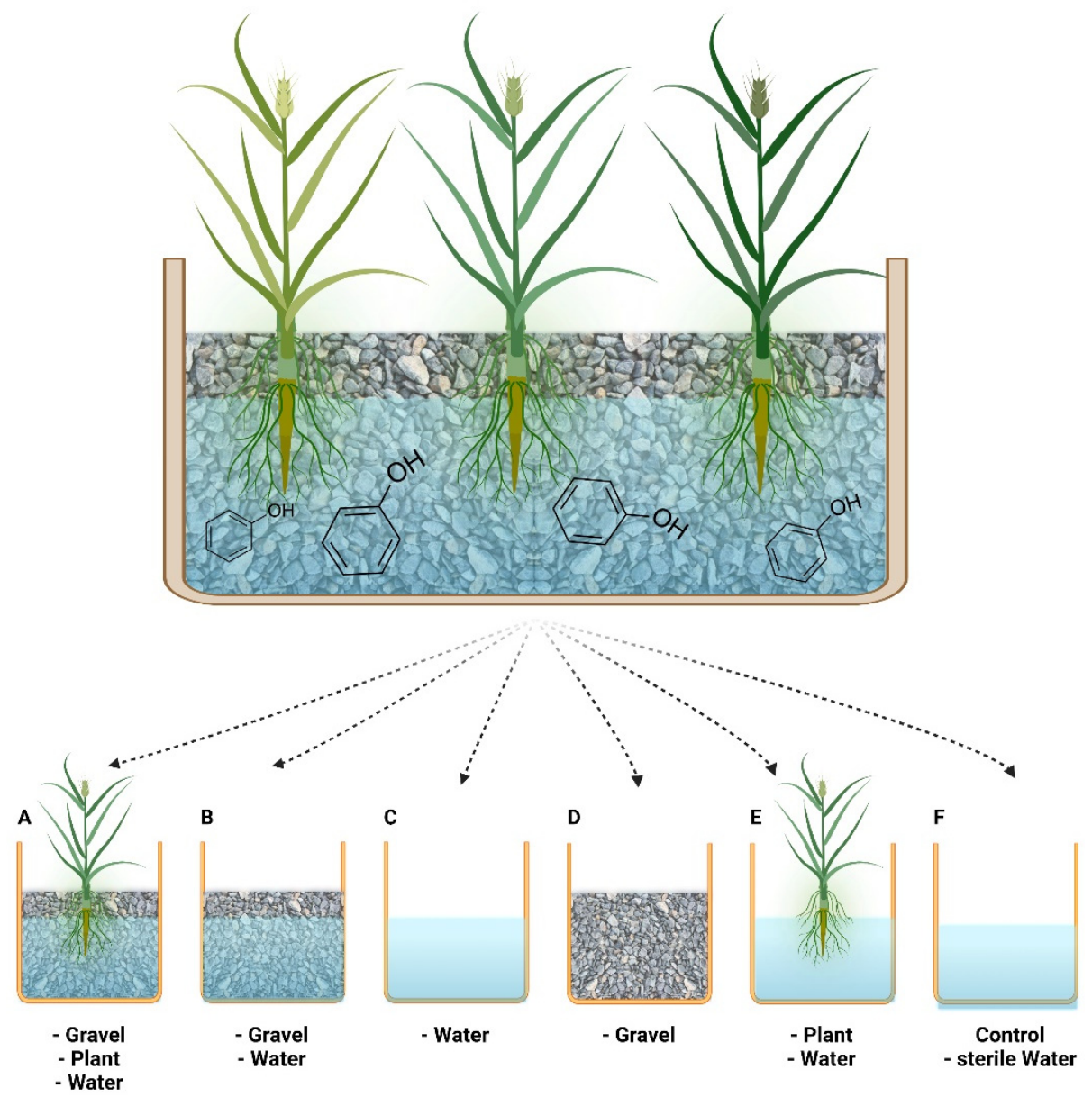

Figure 1. Schematic illustration of the different components of a sub-surface flow CW. Bottom: Illustration of an experimental procedure in which constructed wetland system components are transferred to different tanks in order to monitor the partial contribution of each component to the overall purification process. This includes the following treatments: (A) gravel, plant, water; (B) gravel, water; (C) water; (D) gravel; (E) plant; (F) control (sterile water). The figure was created with BioRender.com. (accessed on 14 February 2022).

Here, I will focus on the contributions of the three main components-plants, porous bed, and microorganisms - to the total removal of phenol (a model industrial contaminant) in subsurface flow CWs. Phenol $\left(\mathrm{C}_{6} \mathrm{H}_{5} \mathrm{OH}\right)$ forms the main building block of polycyclic aromatic hydrocarbons (PAHs), which have both carcinogenic and mutagenic properties, and thus pose a serious threat to the health of both humans and the environment. According to Zhao et al. [12], the use and efficacy of CWs for removal of PAH from effluent has yet to be analyzed in depth, despite the higher cost effectiveness and environmentally friendly nature of this approach with respect to other methods. Degradation of PAH produces 
phenol [13,14]; the ease of monitoring phenol concentrations in the influent and effluent of CW systems makes such systems an attractive choice for phenol removal. This has been shown by a number of studies [15-20], which reported total or high (90\%) removal of phenols from water through a process of mineralization in CWs.

In general, the purification processes in CWs include biodegradation, filtration, sorption, plant uptake, and sedimentation. Although the partial significance of each process to the overall purification depends on the characteristics of the pollutant, the adsorption and volatilization of phenol have been shown to be negligible compared to the biological degradation [21,22]. Furthermore, studies suggested that the extent of plant uptake contribution to the overall removal of phenol is insignificant, and indicated that the major role of plants and their root system is to facilitate microbial degradation by providing a suitable habitat for biofilm growth $[22,23]$. This mini review will discuss the proportionate contribution of each of the CW components-plants roots, porous bed (gravel), and water-to total phenol removal, with and without the contribution of microorganisms.

\section{The Partial Contribution of Plants to Phenol Removal}

Previous research has demonstrated phenol removal by plants at different rates [24] and using different plant species, including soybean [25], alfalfa [26], and willow [27]. It is unclear whether sterility was maintained in all studies, thus we cannot unequivocally state that phenol removal was always performed by the plants alone. Indeed, a study by Kurzbaum et al. [28], using non-sterile vs. sterile plants (antibiotic supplementation to prevent rhizospheric bacterial activity), showed that plants alone contribute very little to overall phenol removal, compared with the native bacterial population.

Studies have shown that plant roots act not only as attachment substrates, but also provide a favorable environment for root-attached microorganisms, supplying important biological exudates, including amino acids, simple sugars, complex carbohydrates, and oxygen $[8,29,30]$. Few of these studies have explored the favorable environment provided by plant roots in CW systems, in comparison with inert surfaces (e.g., porous bed, gravel etc.). In particular, the magnitude of this "rhizosphere effect" is unclear, considering the continuous movement of the wastewater, which dilutes the exudates and washes them away from the roots. Thus, it is not clear to what extent the plant-microbial interaction accelerates biodegradation in comparison to the porous bed-microbial interaction. Many studies have shown that macrophytes (i.e., plants) have a positive effect on contaminant removal in CW systems [31-33], although whether this beneficial effect results from the higher surface area of the plant roots or the supply of essential nutrients for microbial metabolism has yet to be proven. Other studies have claimed that plants actually absorb and adsorb some of the phenols and other organic contaminants directly into their own tissues [34], although Kurzbaum et al. [35] found that the plant contribution alone (using sterile plants) contributes a negligible part of pollutant removal compared to the $\mathrm{CW}$ bacterial community.

One of the most significant components of a wetland system is the plants that it supports. There is a broad consensus that the overall contribution of plants to wastewater treatments in CWs is beneficial, but expertise for designing and maintaining plantations is still lacking [36]. Moreover, there is no consensus regarding the ways plants promote effective water treatment in CWs. The benefit of plants to CWs depends primarily on the type of CW-its direction (horizontal or vertical) and type of flow (surface or subsurface), and the presence or absence of recirculation. Other factors, such as wastewater quantity and quality, treatment medium, plant species composition, plant management, and climate, are also significant.

Planted wetlands have been shown to effectively remove pollutants with no adverse effects on the plants themselves. In their study on CW systems, Polprasert et al. [16] used cattail (Typha) species to remove phenols and other organic compounds. Regarding phenol removal, this review clarifies the importance of plants for phenol degradation through 
the large habitat provided by the roots to the microbial biofilm, rather than through the adsorption, absorption and phytodegradation of the phenols in the treated water.

\section{The Partial Contribution of Planktonic Bacteria and Gravel/Root Biofilms to Phenol Removal}

Biodegradation of phenols by microorganisms in CW systems occurs through aerobic and anaerobic microorganisms [18]. Although many studies refer to CW systems treating sewage mostly as anaerobic, Stottmeister et al. [8] suggested a thin layer of aerobic conditions on the root surface causing some oxygen release from the helophytes' roots.

Under aerobic conditions, oxygen is used as an electron acceptor in the phenol biodegradation process by various species of bacteria and fungi [21]. Phenol-degrading aerobic bacteria can transform phenol into intermediates that enter the tricarboxylic acid cycle through ortho- or meta-pathways of degradation. The first step in both degradation pathways is monohydroxylation at the o-position of the aromatic ring by the enzyme monooxygenase: phenol hydroxylase. Anaerobic phenol degradation occurs under nitratereducing, sulfate-reducing, methanogenic, and iron-reducing conditions. The studies by Sikkema et al. [37] and Krastanov et al. [38] describe phenol degradation by yeasts and filamentous fungi as an ortho-mechanism (3-oxoadipate pathway) whose intermediates enter the central metabolism as succinate and acetyl-S-CoA.

The various bacterial populations in CW systems have been investigated to a limited extent. Gagnon et al. [39] explored the effect of plant presence on the density and activity of the microorganisms, while Pollard et al. [40] studied how emergent plants are affected by stem-attached biofilms. Toyama et al. [41] investigated the biodegradation performance of both rhizosphere and suspended bacterial populations, while Collins et al. [42] compared the water treatment capabilities of CW mesocosms using real plants, plastic plants, or no plants, alongside the bacterial communities. Plant roots and the porous bed were both shown to be significant for bacterial colonization; however, these studies do not allow these two surfaces and their activity to be directly compared in CW systems. Based on current knowledge, we would assume that biofilm bacteria, having greater mass, would contribute more significantly than planktonic bacteria to removal of organic contaminants $[40,43]$.

In a pilot-scale CW treating effluent with low organic matter content (31 mg/L COD), Kurzbaum et al. [23] were able to attribute $95 \%$ of phenol removal to the action of biofilms (on roots and porous bed), while only $5 \%$ was attributed to the planktonic population. Contributions by other processes (phenol evaporation, photolysis, and adsorption onto plants and the porous bed) were deemed negligible. The various components of the CW system used in this study were split across several treatments to examine each component separately (Figure 1) where separated tanks contained (A) gravel, plant, water; (B) gravel, water; (C) water; (D) gravel; (E) plant; (F) control (sterile water).

Within the biofilm component, the root-attached biofilm was found to play a much more significant role than the gravel-attached biofilm, mainly due to greater total numbers of bacteria (including those specializing in phenol degradation) on the root surface. Moreover, the gravel-attached biofilm was four-fold more efficient than the planktonic bacteria at degrading phenol, again due to greater bacterial numbers on the gravel bed compared to an equal volume of planktonic bacteria. Similarly, previous studies have suggested that biofilm development on a hard surface, particularly under starvation conditions, supplies a more beneficial habitat for bacteria $[44,45]$, while other studies have shown that the larger surface area and exudates supplied by the plant rhizosphere provide a more favorable environment than inert gravel $[8,46]$.

When the effluent has a high concentration of organic matter, $\mathrm{CW}$ treatment may facilitate biofilm development on any surface, thus the contributions of the plant roots and the gravel bed may be equivalent. After separating CW components among tanks and monitoring phenol degradation, Kurzbaum et al. [47] were able to attribute the highest contribution to phenol degradation to the gravel-attached biofilm, while the contributions and rates of phenol degradation of the root-attached biofilm and planktonic bacteria were 
negligible (see graphical abstract for a schematic illustration of the experimental system). In this case, the numbers of specialized phenol degraders were much higher on the gravel surface. Higher total numbers of bacteria on the gravel surface compared to the root surface were attributed to the high surface area of the gravel, although a comparison of the actual surface area of these two components was difficult to perform. The stark differences between the findings of this study and those of Kurzbaum et al. [23] are due to the more concentrated effluent (435 mg/L COD) used by Kurzbaum et al. [47].

Thus, in the concentrated effluent, root and gravel surfaces function equally as attachment surfaces, refuting the notion that the root surface provides a more favorable environment for biofilm development, as suggested by previous studies $[8,46,48]$. Thus, it appears that the higher concentration of organic matter in the wastewater downplays any advantage provided by the root surface (as a habitat: rhizodeposition etc.) over the gravel surface for bacterial colonization.

In terrestrial environments, the plant root surface is considered to provide a very favorable environment for microorganisms in both the rhizoplane and rhizosphere [49]; roots release a diverse array of metabolites [34], such as those inducing genes for degradation of contaminants $[50,51]$, as well as those that expedite the degradation of resistant organics [52]. Notwithstanding, in aquatic CW environments, root-attached biofilms are not unequivocally more efficient than gravel-attached biofilms at phenol degradation, probably due to the dilution of root exudates near the root surface and the high concentration of organic matter in the wastewater. Therefore, there is very little advantage of the exudate effect in the root rhizosphere in CW systems, despite the strong advantage of this effect for microorganisms in terrestrial systems (see also [53]).

In another study, Kurzbaum et al. [35] compared the activity of the same three components - root-attached biofilm, gravel-attached biofilm, and planktonic populationin a CW microcosm inoculated with only one bacterial culture of the strain Pseudomonas pseudoalcaligenes. The researchers expected the root biofilm to be the most effective at phenol removal, due to the production of root exudates. Surprisingly, the gravel-attached biofilm performed equally as well as the root-attached biofilm, and the phenol removal rate of the planktonic bacteria was found to be 22-fold greater than that of the biofilms (calculated based on phenol degradation divided by bacterial numbers), while the performance of the sterile components (i.e., liquid medium, plant root, gravel bed) was inconsequential. It was also found that young, thin biofilms developing on roots and gravel performed significantly better than denser biofilms grown on roots and gravel before the experiment began; van Loosdrecht et al. [44] attributes this to the poorer ability of dense biofilms for mass transfer of phenols and oxygen. Given all of the above, this issue is still under debate in the scientific community. Some studies have shown higher removal of phenols and other substrates by planktonic Pseudomonas spp. cells compared to biofilms [54,55], and similarly in other species of bacteria [54-56]. In contrast, other studies have reported greater efficiency of substrate removal and higher respiration rates of biofilms compared to planktonic cells $[57,58]$, while still other studies have reported no difference between biofilms and planktonic bacteria $[59,60]$.

The ability of biological systems to remove high concentrations of phenols is impacted by the toxic effects of these organic compounds on the phenol-degrading bacteria. Such effects can be diminished by maintaining strict operating conditions and acclimatizing the bacterial biomass to the phenols prior to initiation of treatment. As claimed in this review and confirmed by other studies, microbial biodegradation is the main approach to phenol removal in CW systems. However, the presence of plants benefits the phenoldegrading bacteria by providing a large attachment surface and rhizodeposition secretion as a carbon source for microbes in CW systems, especially when treating low-strength wastewater $[8,46,48]$. 


\section{Conclusions}

In this review, phenol degradation by the main components of subsurface flow CW systems - porous bed, plant root, and bacteria-has been described in detail. Furthermore, the effect of the organic matter content of the water on the growth and performance of the different bacterial components-root-attached biofilm, gravel-attached biofilm, and planktonic bacteria-has been detailed. Although many studies have focused on describing and monitoring the contribution of CW system components to the purification process, few have focused on describing the partial contribution of the three bacterial groups (namely root-attached, gravel-attached, and planktonic) to pollutant degradation, such as described in this review. Additional research is required to elucidate the interactions among plants, microorganisms, and the porous media, particularly with respect to any synergistic or antagonistic effects. One direction for future research could be the contribution of the rhizodeposition effect to the degradation of recalcitrant organics (as a source of co-metabolites and catalysts for enzymatic processes). Another research direction could be the addition of attachment surfaces (such as fibers, wood chips etc.) to the CW in addition to the gravel and plants, to increase biofilm amounts and niches in order to reduce the HRT needed for efficient treatment. Finally, research on successful bioaugmentation processes for degrading specific pollutants in CW systems will open up new opportunities in this field, especially with respect to industrial wastewater and wastewater rich in micropollutants. Water purification by $\mathrm{CW}$ systems can be improved once we better understand the underlying mechanisms of purification by root-attached, gravel-attached, and planktonic bacteria.

Funding: This research received no external funding.

Institutional Review Board Statement: No ethical approval was necessary for this manuscript.

Informed Consent Statement: Not applicable.

Data Availability Statement: Data are available to be shared at any request.

Conflicts of Interest: The author declares no conflict of interest.

\section{References}

1. Kadlec, R.; Knight, R. Treatment Wetlands; Lewis Publishers: Chelsea, MI, USA, 1996.

2. Vymazal, J. (Ed.) Natural and Constructed Wetlands: Nutrients, Heavy Metals and Energy Cycling, and Flow; Springer: Cham, Switzerland, 2016.

3. Vymazal, J. Horizontal sub-surface flow and hybrid constructed wetlands systems for wastewater treatment. Ecol. Eng. 2005, 25, 478-490. [CrossRef]

4. Ji, Z.; Tang, W.; Pei, Y. Constructed wetland substrates: A review on development, function mechanisms, and application in contaminants removal. Chemosphere 2022, 286, 131564. [CrossRef]

5. Costerton, J.W.; Lewandowski, Z.; Caldwell, D.E.; Korber, D.R.; Lappin-Scott, H.M. Microbial biofilms. Annu. Rev. Microbiol. 1995, 49, 711-745. [CrossRef] [PubMed]

6. Otte, M.L.; Jacob, D.L. Constructed wetlands for phytoremediation: Rhizofiltration, phytostabilisation and phytoextraction. In Phytoremediation and Rizhoremediation; Mackova, M., Dowling, D.N., Macek, T., Eds.; Springer: Dordrecht, The Netherlands, 2006; pp. 57-67.

7. Danhorn, T.; Fuqua, C. Biofilm formation by plant-associated bacteria. Annu. Rev. Microbiol. 2007, 61, 401-422. [CrossRef]

8. Stottmeister, U.; Wießner, A.; Kuschk, P.; Kappelmeyer, U.; Kästner, M.; Bederski, O.; Müller, R.; Moormann, H. Effects of plants and microorganisms in constructed wetlands for wastewater treatment. Biotechnol. Adv. 2003, 22, 93-117. [CrossRef]

9. Brix, H. Functions of macrophytes in constructed wetlands. Water Sci. Technol. 1994, 29, 71-78. [CrossRef]

10. Vacca, G.; Wand, H.; Nikolausz, M.; Kuschk, P.; Kästner, M. Effect of plants and filter materials on bacteria removal in pilot-scale constructed wetlands. Water Res. 2005, 39, 1361-1373. [CrossRef]

11. Zhu, H.; Zhou, Q.-W.; Yan, B.-X.; Liang, Y.-X.; Yu, X.-F.; Gerchman, Y.; Cheng, X.-W. Influence of vegetation type and temperature on the performance of constructed wetlands for nutrient removal. Water Sci. Technol. 2018, 77, 829-837. [CrossRef]

12. Zhao, C.; Xu, J.; Shang, D.; Zhang, Y.; Zhang, J.; Xie, H.; Kong, Q.; Wang, Q. Application of constructed wetlands in the PAH remediation of surface water: A review. Sci. Total Environ. 2021, 780, 146605. [CrossRef]

13. Nzila, A. Biodegradation of high-molecular-weight polycyclic aromatic hydrocarbons under anaerobic conditions: Overview of studies, proposed pathways and future perspectives. Environ. Pollut. 2018, 239, 788-802. [CrossRef] 
14. Srivastava, S.; Kumar, M. Biodegradation of polycyclic aromatic hydrocarbons (PAHs): A sustainable approach. In Sustainable Green Technologies for Environmental Management; Shah, S., Venkatramaman, V., Prasad, R., Eds.; Springer: Singapore, 2019; pp. 111-139.

15. Seidel, K. Phenol-Abbau in Wasser durch Scirpus lacustris L. wehrend einer versuchsdauer von 31 Monaten. Naturwissenschaften 1965, 52, 398-406. [CrossRef]

16. Polprasert, C.; Dan, N.P.; Thayalakumaran, N. Application of constructed wetlands to treat some toxic wastewaters under tropical conditions. Water Sci. Technol. 1996, 34, 165-171. [CrossRef]

17. Abira, M.A.; van Bruggen, J.J.A.; Denny, P. Potential of a tropical subsurface constructed wetland to remove phenol from pre-treated pulp and papermill wastewater. Water Sci. Technol. 2005, 51, 173-176. [CrossRef] [PubMed]

18. Tee, H.C.; Seng, C.E.; Noor, A.M.; Lim, P.E. Performance comparison of constructed wetlands with gravel- and rice husk-based media for phenol and nitrogen removal. Sci. Total Environ. 2009, 407, 3563-3571. [CrossRef]

19. Poerschmann, J.; Schultze-Nobre, L. Sorption determination of phenols and polycyclic aromatic hydrocarbons in a multiphase constructed wetland system by solid phase microextraction. Sci. Total Environ. 2014, 482, 234-240. [CrossRef]

20. Abedi, T.; Mojiri, A. Constructed wetland modified by biochar/zeolite addition for enhanced wastewater treatment. Environ. Technol. Innov. 2019, 16, 100472. [CrossRef]

21. Stefanakis, A.I.; Thullner, M. Fate of phenolic compounds in constructed wetlands treating contaminated water. In Phytoremediation; Ansari, A.A., Gill, S.S., Gill, R., Lanza, G.R., Newman, L., Eds.; Springer: Cham, Switzerland, 2016; pp. $311-325$.

22. Mojiri, A.; Ahmad, Z.; Tajuddin, R.M.; Arshad, M.F.; Gholami, A. Ammonia, phosphate, phenol, and copper(II) removal from aqueous solution by subsurface and surface flow constructed wetland. Environ. Monit. Assess. 2017, 189, 337. [CrossRef]

23. Kurzbaum, E.; Zimmels, Y.; Kirzhner, F.; Armon, R. Removal of phenol in a constructed wetland system and the relative contribution of plant roots, microbial activity and porous bed. Water Sci. Technol. 2010, 62, 1327-1334. [CrossRef]

24. Cunningham, S.D.; Anderson, T.A.; Schwab, A.P.; Hsu, F.C. Phytoremediation of soils contaminated with organic pollutants of outstanding interest. Adv. Agron. 1996, 56, 55-114.

25. McFarlane, J.C.; Pfleeger, T.; Fletcher, J. Transpiration effect on the uptake and distribution of bromacil, nitrobenzene, and phenol in soybean plants. J. Environ. Qual. 1987, 16, 372-376. [CrossRef]

26. Flocco, C.G.; Lo Balbo, A.; Carranza, M.P.; Giulietti, A.M. Removal of phenol by alfalfa plants (Medicago sativa L.) grown in hydroponics and its effect on some physiological parameters. Acta Biotechnol. 2002, 22, 43-54. [CrossRef]

27. Ucisik, A.S.; Trapp, S. Uptake, removal, accumulation, and phytotoxicity of phenol in willow trees (Salix viminalis). Environ. Toxicol. Chem. 2006, 25, 2455-2460. [CrossRef] [PubMed]

28. Kurzbaum, E.; Kirzhner, F.; Armon, R. A Hydroponic system for growing gnotobiotic vs. sterile plants to study phytoremediation processes. Int. J. Phytoremediat. 2014, 16, 267-274. [CrossRef] [PubMed]

29. Gersberg, R.M.; Eikins, B.V.; Lyon, S.R.; Goldman, C.R. Role of aquatic plants in wastewater treatment by artificial wetlands. Water Res. 1986, 20, 363-368. [CrossRef]

30. Brix, H. Do macrophytes play a role in constructed treatment wetland? Water Sci. Technol. 1997, 35, 7-11. [CrossRef]

31. Tanner, C.C. Plants for constructed wetland treatment systems-A comparison of the growth and nutrient uptake characteristics of eight emergent species. Ecol. Eng. 1996, 7, 59-83. [CrossRef]

32. Brisson, J.; Chazarenc, F. Maximizing pollutant removal in constructed wetlands: Should we pay more attention to macrophyte species selection? Sci. Total Environ. 2009, 407, 3923-3930. [CrossRef]

33. Zimmels, Y.; Kirzhner, F.; Schreiber, J. Removal of high organic loads from winery wastewater by aquatic plants. Water Environ. Res. 2008, 80, 806-822. [CrossRef]

34. Tsao, D.T. Phytoremediation: Advances in Biochemical Engineering/Biotechnology; Springer: Berlin/Heidelberg, Germany, 2003; Volume 78.

35. Kurzbaum, E.; Kirzhner, F.; Sela, S.; Zimmels, Y.; Armon, R. Efficiency of phenol biodegradation by planktonic Pseudomonas pseudoalcaligenes (a constructed wetland isolate) vs. root and gravel biofilm. Water Res. 2010, 44, 5021-5031. [CrossRef]

36. Shelef, O.; Gross, A.; Rachmilevitch, S. Role of plants in a constructed wetland: Current and new perspectives. Water 2013, 5, 405-419. [CrossRef]

37. Sikkema, J.; de Bont, J.A.; Poolman, B. Mechanisms of membrane toxicity of hydrocarbons. Microbiol. Rev. 1995, 59, 201-222. [CrossRef] [PubMed]

38. Krastanov, A.; Alexieva, Z.; Yemendzhiev, H. Microbial degradation of phenol and phenolic derivatives. Eng. Life Sci. 2013, 13, 76-87. [CrossRef]

39. Gagnon, V.; Chazarenc, F.; Comeau, Y.; Brisson, J. Influence of macrophyte species on microbial density and activity in constructed wetlands. Water Sci. Technol. 2007, 56, 249-254. [CrossRef] [PubMed]

40. Pollard, P.C.; Flood, J.A.; Ashbolt, N.J. The direct measurement of bacterial growth in biofilms of emergent plants (Schoenoplectus) of an artificial wetland. Water Sci. Technol. 1995, 32, 251-256. [CrossRef]

41. Toyama, T.; Yu, N.; Kumada, H.; Sei, K.; Ike, M.; Fujita, M. Accelerated aromatic compounds degradation in aquatic environment by use of interaction between Spirodela polyrrhiza and bacteria in its rhizosphere. J. Biosci. Bioeng. 2006, 101, 346-353. [CrossRef] [PubMed]

42. Collins, B.; McArthur, J.V.; Sharitz, R.R. Plant effects on microbial assemblages and remediation of acidic coal pile runoff in mesocosm treatment wetlands. Ecol. Eng. 2004, 23, 107-115. [CrossRef] 
43. Polprasert, C.; Khatiwada, N.R. An integrated kinetic model for water hyacinth ponds used for wastewater treatment. Water Res. 1998, 32, 179-185. [CrossRef]

44. Van Loosdrecht, M.C.M.; Lyklema, J.; Norde, W.; Zehnder, A.J.B. Influence of interfaces on microbial activity. Microbiol. Rev. 1990, 54, 75-87. [CrossRef]

45. Dawson, M.P.; Humhrey, B.A.; Marshall, K.C. Adhesion: A tactic in the survival strategy of a marine vibrio during starvation. Curr. Microbiol. 1981, 6, 195-198. [CrossRef]

46. Tanner, C. Plants as ecosystem engineers in subsurface-flow treatment wetlands. Water Sci. Technol. 2001, 44, 9-17. [CrossRef]

47. Kurzbaum, E.; Kirzhner, F.; Armon, R. Performance comparison of plant root biofilm, gravel attached biofilm and planktonic microbial populations, in phenol removal within a constructed wetland wastewater treatment system. Water $S A$ 2016, 42, 166-170. [CrossRef]

48. Moormann, H.; Kuschk, P.; Stottmeister, U. The effect of rhizodeposition from helophytes on bacterial degradation of phenolic compounds. Acta Biotechnol. 2002, 22, 107-112. [CrossRef]

49. Varma, A.; Abbott, L.; Werner, D.; Hampp, R. Plant Surface Microbiology; Springer: Berlin/Heidelberg, Germany; New York, NY, USA, 2007.

50. Gilbert, E.S.; Crowley, D. Plant compounds that induce polychlorinated biphenyl biodegradation by Arthrobacter sp. strain B1B. Appl. Environ. Microbiol. 1997,63, 1933-1938. [CrossRef] [PubMed]

51. Casavant, N.C.; Thompson, D.; Beattie, G.A.; Phillips, G.J.; Halverson, L.J. Use of a site-specific recombination-based biosensor for detecting bioavailable toluene and related compounds on roots. Environ. Microbiol. 2003, 5, 238-249. [CrossRef]

52. Rentz, J.A.; Alvarez, P.J.; Schnoor, J.L. Benzo[a]pyrene co-metabolism in the presence of plant root extracts and exudates: Implications for phytoremediation. Environ. Pollut. 2005, 136, 477-484. [CrossRef]

53. Hussain, F.; Mustufa, G.; Zia, R.; Faiq, A.; Matloob, M.; Shah, H.-U.-R.; Ali, W.R.; Irfan, J.A. Constructed wetlands and their role in remediation of industrial effluents via plant-microbe interaction-A mini review. J. Bioremediat. Biodegrad. 2018, 9, 447. [CrossRef]

54. Barton, A.J.; Sagers, R.D.; Pitt, W.G. Measurement of bacterial growth rates on polymers. J. Biomed. Mater. Res. 1996, 32, 271-278. [CrossRef]

55. Heffernan, B.; Murphy, C.D.; Casey, E. Comparison of planktonic and biofilm cultures of Pseudomonas fluorescens DSM 8341 cells grown on fluoroacetate. Appl. Environ. Microbiol. 2009, 75, 2899-2907. [CrossRef]

56. Jeffrey, W.H.; Paul, J.H. Activity of an attached and free-living Vibrio sp. as measured by thymidine incorporation, piodonitrotetrazolium reduction, and ATP/ADP ratios. Appl. Environ. Microbiol. 1986, 51, 150-156. [CrossRef]

57. Ascon-Cabrera, M.A.; Ascon-Reyes, D.B.; Lebeault, J.M. Degradation activity of adhered and suspended Pseudomonas cells cultured on 2,4,6-trichlorophenol, measured by indirect conductimetry. J. Appl. Bacteriol. 1995, 79, 617-624. [CrossRef]

58. Bester, E.; Wolfaardt, G.; Joubert, L.; Garny, K.; Saftic, S. Planktonic-cell yield of a pseudomonad biofilm. Appl. Environ. Microbiol. 2005, 71, 7792-7798. [CrossRef] [PubMed]

59. Bright, J.J.; Fletcher, M. Amino acid assimilation and electron transport system activity in attached and free-living marine bacteria. Appl. Environ. Microbiol. 1983, 45, 818-825. [CrossRef] [PubMed]

60. Iriberri, J.; Unanue, M.; Barcina, I.; Egea, L. Bacterial production and growth rate estimation from [3 H]thymidine incorporation for attached and free-living bacteria in aquatic systems. Appl. Environ. Microbiol. 1990, 56, 483-487. [CrossRef] [PubMed] 